\title{
Aminorex and the pulmonary circulation
}

\author{
J. M. KAY, PAUL SMITH, AND DONALD HEATH \\ Department of Pathology, University of Liverpool
}

\begin{abstract}
Aminorex (2-amino-5-phenyl-2-oxazoline) is an appetite-suppressing drug which was available in Switzerland from November 1965 to October 1968. In 1967 a sudden 20-fold increase in the incidence of primary pulmonary hypertension was observed in a Swiss medical clinic. It was noticed that a considerable number of these patients had taken aminorex to reduce weight. A similar increase in the incidence of primary pulmonary hypertension was encountered in other clinics in Switzerland, and also in Austria and Germany, where aminorex was available. An increased incidence of the disease has not been reported in countries where this drug was not available. A decline in the incidence of primary pulmonary hypertension has occurred in Switzerland since the withdrawal of aminorex. We have administered a high oral dose of aminorex to rats for up to 43 weeks and to dogs for 20 weeks. A detailed quantitative pathological examination of the heart and pulmonary vasculature in these animals has failed to reveal any evidence of hypertensive pulmonary vascular disease. Although there is statistical evidence linking aminorex with pulmonary hypertension, there is no proof that aminorex causes hypertensive pulmonary vascular disease in man. It is nevertheless important to enquire into the diet and history of drug ingestion in any patient with unexplained pulmonary hypertension.
\end{abstract}

It has been shown that oral administration of the pyrrolizidine alkaloid, fulvine, to rats produces hypertensive pulmonary vascular disease and eventual death from right ventricular failure (Kay et al., 1971). As a result of this and other studies (Kay, Harris, and Heath, 1967; Burns, 1971) we suggested that a careful enquiry should be made from all patients presenting with unexplained pulmonary hypertension to elicit the possibility that the disease might be related to the ingestion of a drug or plant extract.

The purpose of this paper is to review the evidence linking aminorex, an anorexigen, with an outbreak of 'primary' pulmonary hypertension which occurred recently in western Europe, and to describe experiments in which this drug was given to rats and dogs.

THE CLINICAL BACKGROUND TO OUR INVESTIGATION

The cause of chronic elevation of the pulmonary arterial pressure in a patient is usually fairly obvious. The commoner causes of this condition include pre- and post-tricuspid congenital cardiac shunts, prolonged left atrial hypertension, recurrent pulmonary embolism, parenchymal diseases of the lungs, such as emphysema and pulmonary fibrosis, and chronic alveolar hypoxia. In a small minority of cases the cause of the pulmonary hypertension is not clear, and this residual group of cases has been designated 'primary', 'idiopathic', 'unexplained', or 'essential' pulmonary hypertension. Primary pulmonary hypertension has always been considered a rare condition, comprising about $1 \%$ of adult patients studied by cardiac catheterization. In the latter half of the year 1967, however, a dramatic and sudden change in the incidence of this disease was noticed by Gurtner and his colleagues working at the University Medical Clinic in Berne (Gurtner et al., 1968). The incidence of primary pulmonary hypertension in adults subjected to cardiac catheterization increased from $0.87 \%$ observed during the 12-year period, 1955 to 1966 , to $15.4 \%$ during the years 1967 and 1968 (Gurtner, 1969a). A comparable increase in incidence was noticed in every clinical centre in Switzerland (Rivier, 1970). Similar observations were made in Austria (Kaindl, 1969) and Germany (Lang, Haupt, Köhler, and Schmidt, 1969) where the rise in incidence was less pronounced.

Gurtner and his colleagues were convinced that the sudden 20-fold increase in the incidence of primary pulmonary hypertension in their clinic was not due to chance nor to improved diagnostic procedures (Gurtner et al., 1968). They noted that the majority of patients studied since 1967 differed from their earlier cases in that the recent patients 
tended to be older, showed a more rapid progress of the disease, and were frequently obese. Moreover, a considerable proportion of the individuals studied since the beginning of 1967 had tried to reduce weight by taking aminorex, a potent appetite-suppressing drug. Aminorex (2amino-5-phenyl-2-oxazoline) resembles adrenalin and amphetamine in its chemical structure (Fig. 1)

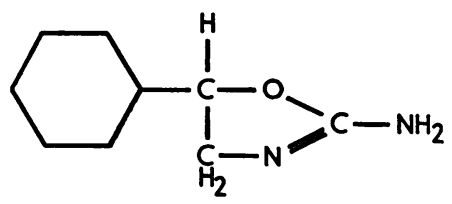

FIG. 1. Structural formula of aminorex.

and suppresses the appetite in most individuals by acting directly on the brain (Peters, 1970). It was introduced on the Swiss market in November 1965 under the proprietary name of Menocil. Gurtner (1970) noted that, of 70 patients (62 females and 8 males) with primary pulmonary hypertension investigated between January 1967 and March 1970, 55 gave a history of having taken aminorex. In these patients, the first symptoms, such as exertional dyspnoea, reduced exercise tolerance, syncope, and right ventricular failure, appeared between 6 and 12 months after commencing the drug. Aminorex was withdrawn from the market in October 1968 and since that date there has been a decline in the incidence of primary pulmonary hypertension (Gurtner, 1969b; Blankart, 1970). These workers have, however, noticed a recent three- to five-fold increase in the incidence of primary pulmonary hypertension in Switzerland unassociated with aminorex ingestion. It is not known whether this increase of pulmonary hypertension unassociated with aminorex is due to an increased awareness of the disease resulting from wide publicity, or to a possible concealment of aminorex consumption, or whether it reflects the operation of other unsuspected aetiological factors. Apart from the temporal relationship between the availability of aminorex and the incidence of primary pulmonary hypertension, there is also a geographical coincidence between the market of the drug and the changed incidence of the disease. Thus an increased incidence of primary pulmonary hypertension has been reported only in countries where the drug has been commercially available (Austria, Germany, and Switzerland); the incidence of the disease does not appear to have changed in countries where the drug has not been marketed (e.g., Great Britain, France, Sweden, Denmark, and the United States of America).

Greiser and Gahl (1970) sorted all the prescription forms of a major health insurance company in Hanover and traced 731 patients known to have taken aminorex, among whom they identified 22 examples of primary pulmonary hypertension. Their criteria for the diagnosis of primary pulmonary hypertension were: a mean pulmonary artery pressure of greater than $20 \mathrm{mmHg}$; a normal pulmonary capillary and/or left atrial pressure; elevation of the pulmonary vascular resistance above 150 dyn-sec-cm ${ }^{-5}$. They showed that in females, the risk of developing pulmonary hypertension after taking aminorex tended to rise with increasing age, and that there was a significant relation between the logarithm of the incidence of primary pulmonary hypertension and the number of aminorex tablets ingested.

Histological studies of the pulmonary blood vessels in biopsy (Obiditsch-Mayer, 1969) and necropsy (Jornod, Widgren, and Fischer, 1970) specimens of lung obtained from patients with primary pulmonary hypertension following aminorex ingestion have been made. Through the courtesy of Professor H. P. Gurtner and Professor $\mathrm{H}$. Cottier of Berne we have been able to examine such material and can confirm that the histological lesions could all be explained as occurring as part of a spontaneous primary pulmonary hypertension (Wagenvoort, Heath, and Edwards, 1964). The elastic pulmonary arteries are atheromatous. There is much medial hypertrophy of the muscular pulmonary arteries (arterial vessels between $100 \mu$ and $1,000 \mu$ in external diameter). These vessels also show intimal fibrosis and fibroelastosis; in some arteries this is severe and of the 'onion-skin' type leading to occlusion of the lumen (Fig. 2). Some of the muscular pulmonary arteries show dilatation lesions of the plexiform (Fig. 3) and angiomatoid type (Heath and Edwards, 1958). The pulmonary arterioles are hypertensive in type, possessing a distinct media of circular muscle bounded by internal and external elastic laminae. The wall of a pulmonary arteriole is normally devoid of muscle and consists simply of a single elastic lamina lined by endothelium. Many pulmonary arterioles are largely occluded by intimal fibrosis and fibroelastosis. These lesions are quite different from those encountered in the hypertensive pulmonary vascular disease of gross obesity-the so-called Pickwickian syndrome (Burwell, Robin, Whaley, and Bickelmann, 1956). In this condition there is 
muscularization of the pulmonary arterioles, an absence of medial hypertrophy in the muscular pulmonary arteries, and the development of intimal longitudinal muscle in both pulmonary arterioles and muscular pulmonary arteries (Hasleton, Heath and Brewer, 1968).

In 1967 it was postulated that some cases of primary pulmonary hypertension encountered in clinical practice might be due to the ingestion of toxic substances in the diet (Kay et al., 1967). This hypothesis was advanced following the observation that oral administration of the pyrrolizidine alkaloid, monocrotaline, to rats produced a severe degree of pulmonary arterial hypertension associated with right ventricular hypertrophy and hypertensive pulmonary vascular disease, which eventually terminated in right ventricular failure and death (Kay and Heath, 1966). The pulmonary vascular lesions consisted of muscularization of the pulmonary arterioles, medial hypertrophy of muscular pulmonary arteries, and thickening of the pulmonary trunk (Heath and Kay, 1967). In about one-third of affected animals there was an

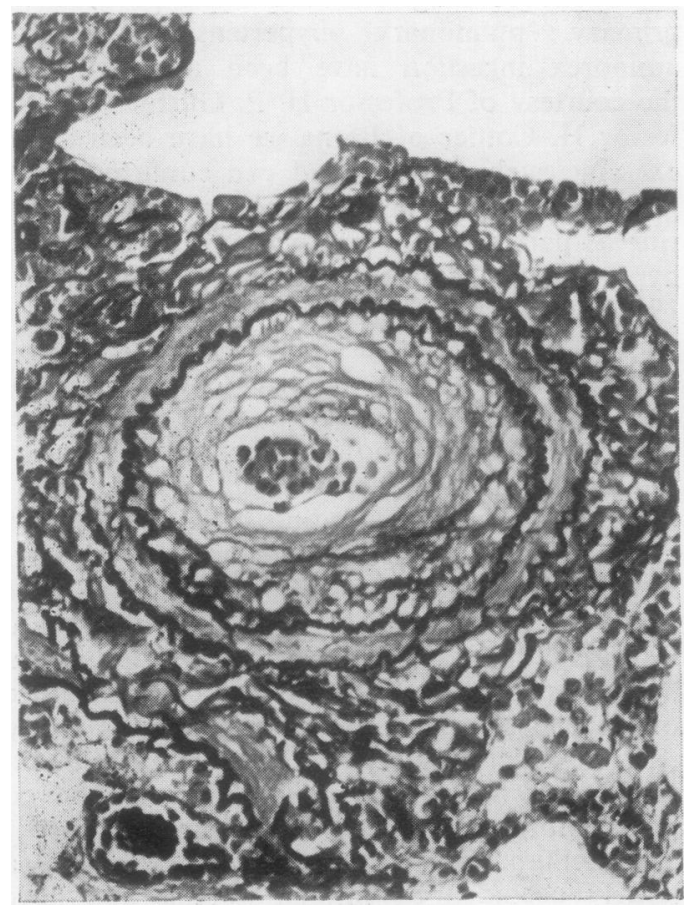

FIG. 2. Muscular pulmonary artery from patient with primary pulmonary hypertension and a history of ingestion of aminorex. The media is thickened and there is a concentric intimal fibroelastic proliferation with pronounced narrowing of the lumen. Elastic-van Gieson $\times 300$.

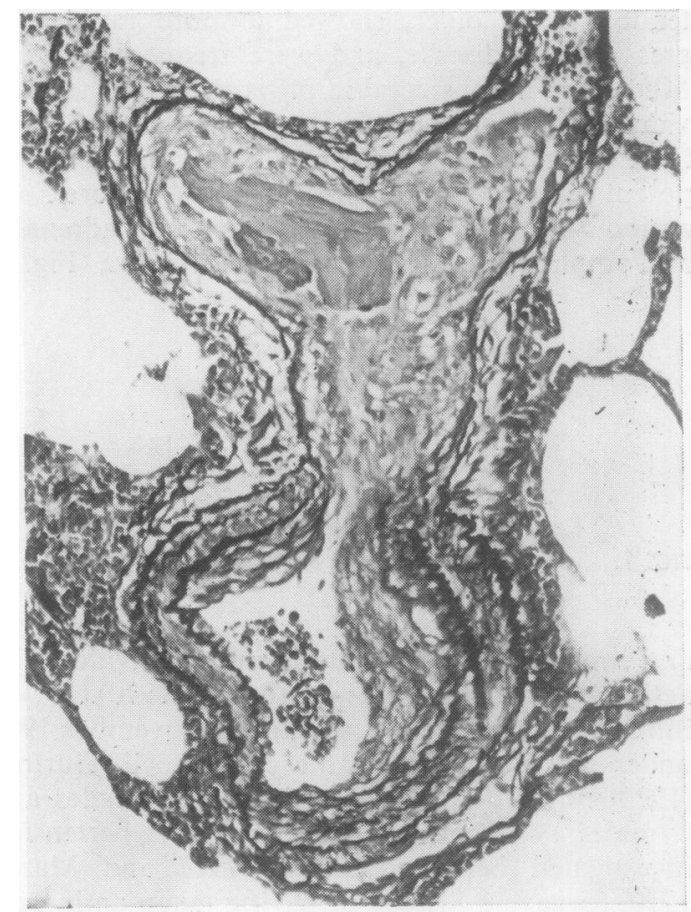

FIG. 3. Dilatation lesion arising in side branch of a muscular pulmonary artery. The parent muscular pulmonary artery (lower half of picture) shows medial hypertrophy and intimal fibroelastosis. The lateral branch (upper half of picture) is occupied by an endothelial cell proliferation and some thrombus, which is characteristic of a plexiform lesion. Same case as in Fig. 2. Elastic-van Gieson $\times 150$.

acute necrotizing pulmonary arteritis. Identical hypertensive pulmonary vascular lesions also occurred in rats given the pyrrolizidine alkaloid, fulvine (Kay et al., 1971). Because the rat was susceptible to the development of hypertensive $\frac{7}{2}$ pulmonary vascular disease we considered it to be a suitable experimental animal in which to investi- N gate the apparent connexion between aminorex and primary pulmonary hypertension. Accord- O ingly, we administered aminorex to a group of $\omega$ rats for a prolonged period and then carried out a quantitative pathological examination of the heart and pulmonary arteries. While this experi- $\mathbb{D}$ ment was in progress we became aware of the ?+ work of Kraupp and his colleagues, who showed ${ }^{\circ}$ that intravenous injection of aminorex into dogs $\frac{O}{\mathbb{D}}$ produced an increase in the pulmonary arterial $\stackrel{\odot}{\odot}$ pressure (Kraupp, Stühlinger, Raberger, and Turn- $\stackrel{\mathbb{Q}}{\varrho}$ heim, 1969). We therefore administered aminorex $\sigma$ to a group of dogs and then performed a similar 
quantitative pathological study of their hearts and pulmonary arteries.

\section{METHODS}

In the first experiment 59 female Wistar albino rats weighing between 55 and $210 \mathrm{~g}$ were divided into a group of 20 controls and a group of 39 test animals. The test rats were given a diet of powdered Thomson rat cubes to which was added aminorex fumarate to give a concentration of $840 \mathrm{mg}$ of the compound per $\mathrm{kg}$ of diet. This ensured that each test rat received a minimum daily dose of $18 \mathrm{mg}$ aminorex base/ $\mathrm{kg}$ body weight. The daily dose of aminorex administered to patients in Switzerland was of the order of $0.15 \mathrm{mg}$ to $0.30 \mathrm{mg} / \mathrm{kg}$ body weight. The control animals were given unadulterated powdered rat cubes. All animals were allowed free access to both food and water. Test rats died spontaneously or were killed with ether after receiving aminorex for periods ranging from 24 to 302 days. Groups of control rats were killed at intervals throughout the course of the experiment. Necropsy was performed as soon as possible using the technique described below.

In the second experiment four female beagle dogs weighing between 5 and $7 \mathrm{~kg}$ were given a single daily oral dose of aminorex fumarate amounting to $6 \mathrm{mg} / \mathrm{kg}$ body weight. A fifth and similar dog served as an untreated control. After 20 weeks all five animals were killed with an intravenous injection of pentobarbitone, and necropsy was performed immediately.

At necropsy, in both experiments, the cervical and thoracic organs were removed from the body in one block. The trachea was cannulated so that the lungs could be distended with buffered neutral formalin. When the pleural surfaces were smooth, the trachea was ligated below the tip of the cannula, which was then withdrawn, and the organs were immersed in fixative. This technique avoids partial collapse of the lung, which may lead to a spurious impression of medial hypertrophy in the small pulmonary blood vessels.

When fixation was complete, the heart was dissected free and opened. Blood and excess fixative were removed by blotting with fine gauze. The cardiac chambers were divided to obtain the weights of the free wall of the right ventricle, the left ventricle together with the interventricular septum, and the two atria. The presence of right ventricular hypertrophy was assessed by expressing the right ventricular weight as a ratio of the final body weight, and also as an inverse ratio of the weight of the left ventricle and interventricular septum. The use of this latter ratio excludes the influence of body weight in making comparisons of right ventricular mass. Blocks of tissue for quantitative histological examination were cut from the pulmonary trunk, ascending aorta, and each of the lobes of both lungs. Sections of these tissues were stained with haematoxylin and eosin and by an elastic-van Gieson method for distinguishing elastic fibres, col- lagen, and smooth muscle. The sections were examined with a microscope fitted with a calibrated eyepiece micrometer. The medial thickness of the pulmonary trunk and aorta was measured as the distance between the internal and external laminae. Ten measurements of the medial thickness were made on each vessel, and from these one mean medial thickness was calculated. The mean medial thickness of the pulmonary trunk was expressed as a ratio of the mean medial thickness of the aorta (PT/A ratio). Measurements of the external diameter and average medial thickness of the muscular pulmonary arteries were made in all the test and control animals. Muscular pulmonary arteries consist of a thin media of circularly orientated smooth muscle fibres retained between internal and external elastic laminae (Figs 7 and 9). Only arteries which were virtually circular in transverse section were measured. The diameter was taken as the mean of two measurements, at right angles to each other, of the distance between diametrically opposite points on the external elastic laminae. The medial thickness was estimated as the mean of four measurements taken at approximately equally spaced points around the vessel wall. The medial thickness was then expressed as a percentage of the external diameter. A value for the average percentage medial thickness in each animal was obtained by totalling all the percentage medial thicknesses and dividing the sum by the number of vessels examined.

\section{RESULTS}

EXPERIMENT ON RATS The numerical data from the control and test rats are summarized in Table I.

Final body weight The final body weight of the rats given aminorex was significantly less than that observed in the untreated control rats.

Cardiac ventricular weights The weight of the left ventricle and interventricular septum was

T A B LE I

FINAL BODY WEIGHT, VENTRICULAR WEIGHTS, AND THICKNESS OF PULMONARY ARTERIES IN CONTROL AND TEST RATS

\begin{tabular}{l|c|c|c|c|c}
\hline \multirow{2}{*}{ Parameter } & \multicolumn{2}{|c|}{ Control Rats } & \multicolumn{2}{c|}{ Test Rats } & \multirow{2}{*}{ P } \\
\cline { 2 - 4 } & Range & Mean & Range & Mean & \\
\hline FBW (g) & $195-290$ & 241 & $95-235$ & 191 & $<0.001$ \\
RV (mg) & $67-133$ & 103 & $43-148$ & 99 & NS \\
LV+S (mg) & $350-655$ & 476 & $266-510$ & 393 & $<0.001$ \\
LV+S/RV & $2.9-6.7$ & 4.7 & $2.6-7.1$ & 4.1 & 0.025 \\
RV/FBW & $2.8-6.4$ & 4.3 & $2 \cdot 7-7.9$ & 5.3 & $<0.005$ \\
(×10 & $1.9-4.6$ & 3.2 & $2.0-6.6$ & 3.3 & NS \\
MT(\%) & $0.34-0.56$ & 0.45 & $0.35-0.61$ & 0.42 & NS \\
PT/A & & & & & \\
\hline
\end{tabular}

FBW = final body weight; $R V=$ right ventricular weight; $L V+S=$ weight of left ventricle and interventricular septum; $M T=$ medial thickness of muscular pulmonary arteries; $\mathbf{P T}=$ medial thickness of pulmonary trunk; $A=$ medial thickness of aorta; $N S=$ not significant. 
significantly smaller in the test rats compared with the controls, but the crude right ventricular weight did not differ significantly in the two groups of animals. However, when the right ventricular weight was expressed as a ratio of the final body weight and as an inverse ratio of the weight of the left ventricle and interventricular septum, there was a statistically significant difference between the control and test rats. Figures 4 and 5 show that in rats killed on the 302nd day of the experiment, the right ventricle tends to be relatively larger in the test animals compared with the controls.

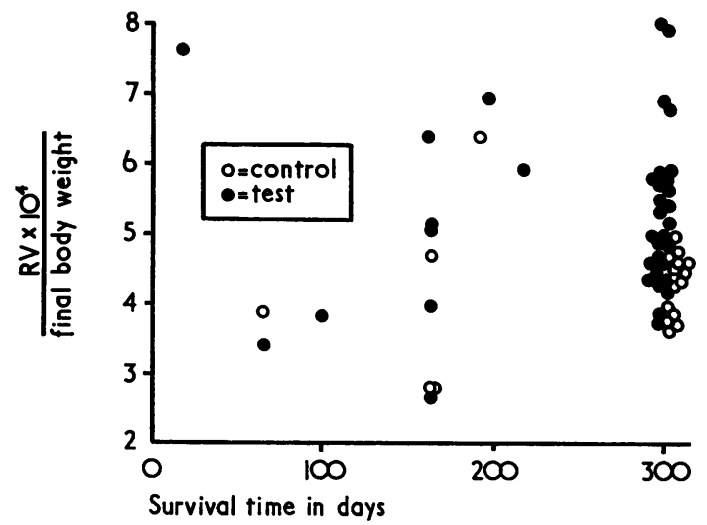

FIG. 4. Experiment on rats. Relation between right ventricular weight and survival time in control rats and rats given aminorex. The right ventricular weight is expressed as a ratio of the final body weight.

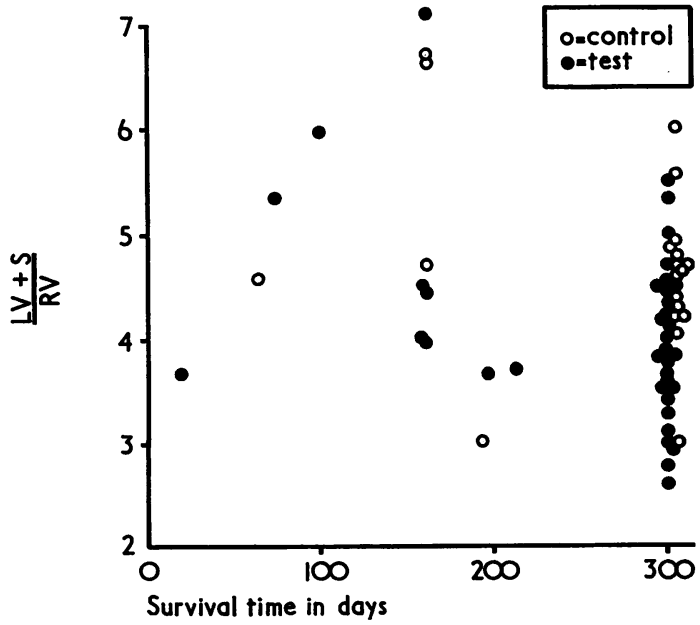

FIG. 5. Experiment on rats. Relation between right ventricular weight and survival time. The right ventricular weight is expressed as an inverse ratio of the weight of the left ventricle and interventricular septum.
Pulmonary trunk This vessel appeared structurally normal and showed no evidence of medial thickening in the rats fed on aminorex. Figure 6 shows the relation between the ratio of medial thickness of the pulmonary trunk to that of the aorta (PT/A ratio) and survival time in days in 39 test rats and 17 controls. There is no evidence of an increase in this ratio after prolonged administration of aminorex.

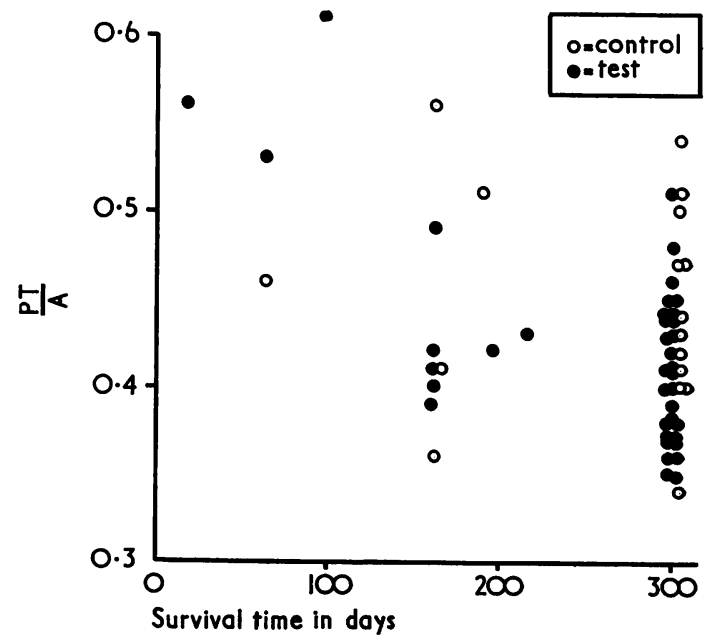

FIG. 6. Experiment on rats. Relation between the medial thickness of the pulmonary trunk and survival time. The medial thickness of the pulmonary trunk is expressed as a ratio of that of the aorta.

Muscular pulmonary arteries These vessels appeared quite normal in both the control and test rats. In every case the media was thin and retained between internal and external elastic laminae (Fig. 7). The rats given aminorex showed no evidence of hypertensive pulmonary vascular disease in the form of medial hypertrophy or necrotizing arteritis, and there was no sign of intimal proliferation. The medial thickness of between 5 and 52 (mean 16) muscular pulmonary arteries was measured in each of the control and test rats. No significant difference was encountered in these two groups of animals (Table I), and Fig. 8 shows that prolonged administration of aminorex is not associated with an increased medial thickness of the muscular pulmonary arteries in rats.

Pulmonary arterioles In the rat this type of vessel measures less than $20 \mu$ in external diameter and is normally devoid of muscle; it consists 


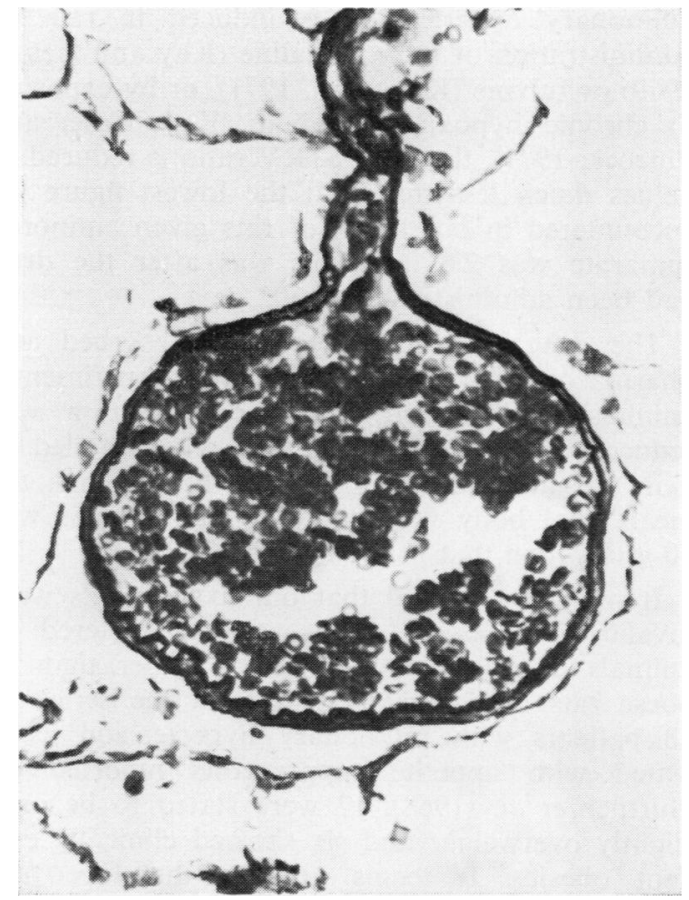

FIG. 7. Experiment on rats. Muscular pulmonary artery from rat fed on aminorex for 302 days. Note the normal, thin, muscular media between internal and external elastic laminae. Elastic-van Gieson $\times 300$.

simply of a single elastic lamina lined by endothelium. The pulmonary arterioles of the rats given aminorex showed no evidence of hypertensive change which would be shown by the formation of a thick muscular media sandwiched between internal and external elastic laminae.

EXPERIMENT ON DOGS The data from the control dog and the four dogs given aminorex are summarized in Table II. None of the dogs showed any evidence of hypertensive pulmonary vascular disease. The hearts did not show right ventricular

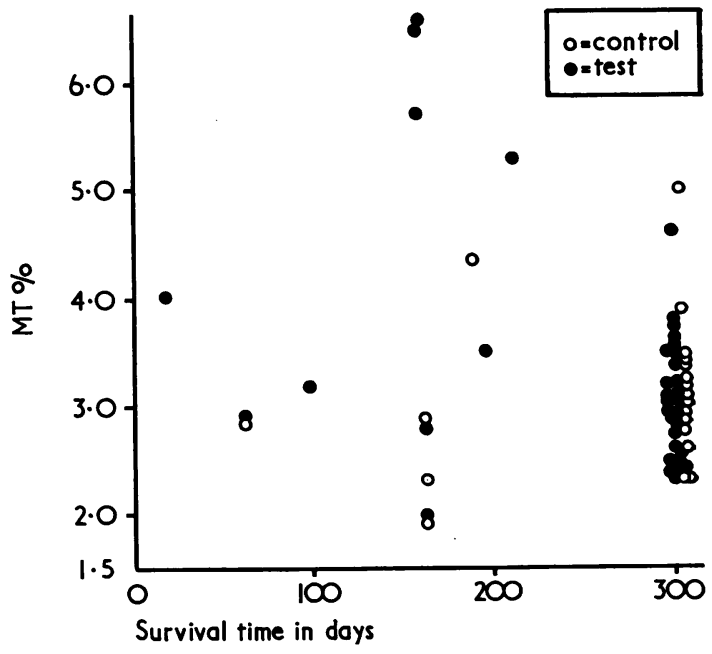

FIG. 8. Experiment on rats. Relation between the average percentage medial thickness of muscular pulmonary arteries and survival time in control and test rats.

hypertrophy, the pulmonary trunk appeared normal, and the pulmonary arteries and arterioles were normal and thin-walled (Fig. 9).

\section{DISCUSSION}

The results of these two experiments show that the prolonged oral administration of high doses of aminorex to rats and dogs did not produce hypertensive pulmonary vascular disease. If significant pulmonary hypertension had developed in these animals we should have expected morphological evidence of this in the form of right ventricular hypertrophy combined with muscularization of the pulmonary arterioles and thickening of the muscular pulmonary arteries and pulmonary trunk.

There was no significant difference between the simple right ventricular weight in the test and

T A B L E I I

HEART WEIGHTS AND THICKNESS OF PULMONARY ARTERIES IN CONTROL AND TEST DOGS

\begin{tabular}{|c|c|c|c|c|c|c|c|c|}
\hline Dog No. & $\begin{array}{c}\text { Aminorex } \\
\text { Fumarate } \\
\text { (mg/kg) }\end{array}$ & $\begin{array}{c}\text { Final Body } \\
\text { Weight } \\
\text { (kg) }\end{array}$ & $\begin{array}{l}\text { Heart } \\
\text { Weight } \\
\text { (g) }\end{array}$ & RV (g) & $\mathbf{L V}+\mathbf{S}(\mathbf{g})$ & $\mathbf{L V}+\mathbf{S} / \mathbf{R V}$ & MT (\%) & $\mathbf{P T} / \mathbf{A}$ \\
\hline $\begin{array}{l}1 \\
2 \\
3 \\
4 \\
5^{1}\end{array}$ & $\begin{array}{l}6 \\
6 \\
6 \\
6 \\
0\end{array}$ & $\begin{array}{l}8 \cdot 1 \\
4 \cdot 7 \\
9 \cdot 2 \\
8 \cdot 1 \\
9 \cdot 5\end{array}$ & $\begin{array}{l}49 \\
40 \\
48 \\
47 \\
57\end{array}$ & $\begin{array}{l}11 \\
11 \\
13 \\
12 \\
14\end{array}$ & $\begin{array}{l}32 \\
25 \\
38 \\
29 \\
36\end{array}$ & $\begin{array}{l}2.9 \\
2.3 \\
2.9 \\
2.4 \\
2.6\end{array}$ & $\begin{array}{l}4 \cdot 6 \\
4 \cdot 2 \\
3 \cdot 1 \\
4 \cdot 0 \\
3 \cdot 6\end{array}$ & $\begin{array}{l}0.47 \\
0.57 \\
0.56 \\
0.47 \\
0.50\end{array}$ \\
\hline
\end{tabular}

${ }^{1}$ Control dog.

See footnote to Table I. 


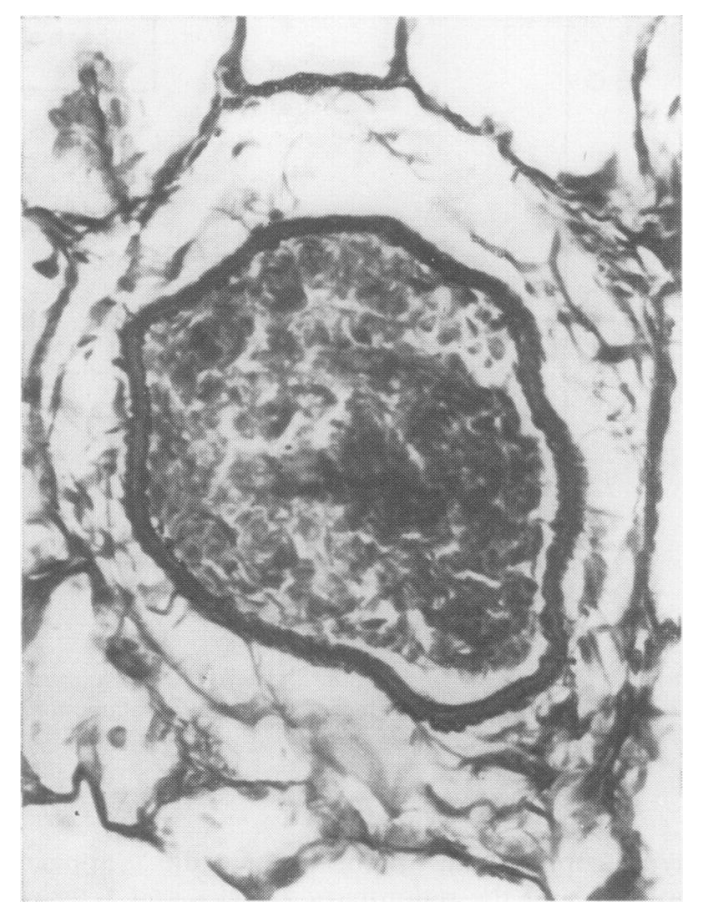

FIG. 9. Experiment on dogs. Normal thin-walled muscular pulmonary artery from test dog no. 2 given aminorex for 20 weeks. Elastic-van Gieson $\times 300$.

control rats, but there was a statistically significant difference between the two groups when the right ventricular weight was expressed as a ratio of the final body weight. Clearly, this apparent right ventricular enlargement in the test rats must be largely a reflection of the low body weight of these animals, resulting from the anorexic effect of aminorex, because the mean final body weight of the test rats was $50 \mathrm{~g}$ less than that in the controls. The influence of body weight can be excluded by expressing the right ventricular weight as an inverse ratio of the weight of the left ventricle and interventricular septum. This reveals a difference in right ventricular size in the two groups of rats which is significant at the $2.5 \%$ level. The reason for this difference is not clear. We do not regard it as an indication of hypertensive pulmonary vascular disease, because no lesions were found after a detailed quantitative examination of the pulmonary blood vessels, and it is inconceivable that a significant degree of chronic pulmonary hypertension could exist without vascular changes in the lungs. Moreover, when pulmonary hypertension is induced in rats by administration of monocrotaline (Kay and Heath, 1969) or fulvine (Kay et al., 1971), or by exposure to chronic hypoxia (Abraham, Kay, Cole, and Pincock, 1971), the $L V+S / R V$ ratio is reduced to values much less than 2.5 ; the lowest figure we encountered in our series of rats given aminorex fumarate was $2 \cdot 6$, and this was after the drug had been administered for 302 days.

The drug seems to have been absorbed and pharmacologically active in the experimental animals, because their food consumption was reduced and they either lost weight or failed to gain weight at the normal rate. In the rats, the mean final body weight of the test animals was $50 \mathrm{~g}$ less than that in the controls.

It might be argued that our experiments were invalid because the drug was administered to animals of normal body weight rather than to obese rats and dogs. However, in the series of 18 patients with pulmonary hypertension associated with appetite suppressants reported by Gurtner et al. (1968), 12 were stated to be only slightly overweight and six showed clinically evident obesity. It seems unlikely therefore that obesity per se played a significant role in the genesis of the pulmonary hypertension in these patients. Moreover, Greiser and Gahl (1970) found that there was no correlation between the frequency of primary pulmonary hypertension and obesity in patients who had taken aminorex. It has been suggested that the reason for the sporadic occurrence of pulmonary hypertension in patients taking aminorex is that in only a small percentage of individuals are the pulmonary blood vessels sensitized to its action by some pre-existing abnormality, such as the cardiopulmonary changes which are known to occur in gross obesity (Burwell et al., 1956; Fishman, Goldring, and Turino, 1966). It is of interest in this connexion to note that Grover and Byrne-Quinn (1970) failed to produce pulmonary hypertension by injecting aminorex into calves in which the pulmonary vasculature was sensitized by chronic hypoxia induced by living at an altitude where the barometric pressure was $625 \mathrm{mmHg}$. In order to exclude the possibility that aminorex produces pulmonary vascular lesions only in obese subjects, we are conducting further experiments using an obese strain of laboratory rat.

Although pharmacologists have demonstrated slight and transient increases in the pulmonary vascular resistance of rats and dogs given aminorex, attempts to produce pulmonary vascular 
disease in these animals have failed. Kraupp et al. (1969) found that intravenous infusion of aminorex into dogs led to a slight increase in the pulmonary blood pressure and vascular resistance which reached a maximum 15 minutes after the beginning of the infusion and remained constant for the duration of the infusion. They concluded that the effect of aminorex on the pulmonary circulation corresponds to the alpha type of sympathomimetic vasomotor action. Engelhardt, Kroneberg, Stoepel, and Stötzer (1970) found that aminorex exerted a transient pressor effect on the pulmonary circulation in dogs, similar to that which is produced by adrenalin. Brunner and Stepanek (1970) gave aminorex to dogs by mouth using a dose of $1.5 \mathrm{mg} / \mathrm{kg}$ body weight for four days. This procedure led to an increase in the pulmonary blood pressure lasting for a number of hours and persisting for several days after repeated administration of the compound. Backmann, Haschemian, Kemper, and Morgenroth (1970) reported perivascular oedema and lymphocytic infiltration in the lungs of rats receiving aminorex for longer than 20 days but stated that right ventricular hypertrophy and thickening of muscular pulmonary arteries did not occur. Engelhardt $e t$ al. (1970) failed to produce hypertensive pulmonary vascular disease in rats and dogs following the administration of aminorex.

The present position with regard to aminorex is that, although there is statistical evidence linking this drug with pulmonary hypertension in man, there is no proof that aminorex causes hypertensive pulmonary vascular disease in human subjects. The fact that administration of aminorex to animals fails to produce hypertensive pulmonary vascular disease does not exclude the possibility that this substance may produce pulmonary hypertension in man. The absence of effect in animals may reflect a species difference in the reactivity. of the pulmonary blood vessels.

Our studies convince us that it is important to enquire into the diet and history of drug ingestion in any patient with unexplained pulmonary hypertension. Some of the anti-obesity agents used in Britain (amphetamine, chlorphentermine, and phenmetrazine) are chemically related to aminorex. Preparations containing Senecio jacobaea (ragwort) are freely available in 'health stores' and herbalists where they are recommended for the treatment of various ailments. Senecio jacohaea contains six pyrrolizidine alkaloids, and Burns (1971) has recently shown that oral administration of this plant to rats produces hypertensive pulmonary vascular disease.
We are grateful to Cilag-Chemie, Schaifhausen, Switzerland for a supply of aminorex fumarate. Professor H. P. Gurtner, Professor H. Cottier, and Dr. Jean Laissue of the University of Berne kindly allowed us to examine lung tissue from patients who developed pulmonary hypertension after treatment with aminorex and to illustrate our findings in Figs 2 and 3.

\section{REFERENCES}

Abraham, A. S., Kay, J. M., Cole, R. B., and Pincock, A. C. (1971). Haemodynamic and pathological study of the effect of chronic hypoxia and subsequent recovery of the heart and pulmonary vasculature of the rat. Cardiovasc. Res., 5, 95.

Backmann, R., Haschemian, A., Kemper, F., and Morgenroth, K. jr. (1970). Influence of anorexigens on the lungs of rats. Read at a symposium on Obesity, circulation and anorexigens, May 15 and 16, Lucerne, Switzerland.

Blankart, R. (1970). Epidemiologic investigations concerning the increase of pulmonary hypertension during the years 1967 to 1969 . Read at a symposium on Obesity, circulation and anorexigens, May 15 and 16, Lucerne, Switzerland.

Brunner, H., and Stepanek, J. (1970). Effects of aminorex on the pulmonary circulation of the dog. Proceedings of the Twelfth Annual Meeting of the European Society for the Study of Drug Toxicity, Uppsala, Sweden, June 1970. Excerpta Medica Foundation, Amsterdam. In press.

Burns, J. (1971). The heart and pulmonary arteries of rats fed on Senecio jacobaea. Pathological Society of Great Britain and Ireland. Synopses of papers read at 122nd meeting in January, 1971. p.7.

Burwell, C. S., Robin, E. D., Whaley, R. D., and Bickelmann, A. G. (1956). Extreme obesity associated with alveolar hypoventilation-a Pickwickian syndrome. Amer. J. Med., 21, 811.

Engelhardt, A., Kroneberg, G., Stoepel, K., and Stötzer, H. (1970). On the effect of sympathomimetic substances on the systemic and pulmonary circulation following acute and chronic administration. Proceedings of the Twelfth Annual Meeting of the European Society for the Study of Drug Toxicity, Uppsala, Sweden, June 1970. Excerpta Medica Foundation, Amsterdam. In press.

Fishman, A. P., Goldring, R. M., and Turino, G. M. (1966). General alveolar hypoventilation: a syndrome of respiratory and cardiac failure in patients with normal lungs. Quart. J. Med., 35, 261.

Greiser, E., and Gahl, K. (1970). Frequency estimations of ingestion of aminorex and incidence of primary pulmonary hypertension in a defined population. Proceedings of the Twelfth Annual Meeting of the European Society for the Study of Drug Toxicity, Uppsala, Sweden, June 1970. Excerpta Medica Foundation, Amsterdam. In press.

Grover, R. F., and Byrne-Quinn, E. (1970). Attempted induction of pulmonary hypertension in the calf with anorexigens. Read at a symposium on Obesity, circulation and anorexigens, May 15 and 16, Lucerne, Switzerland. 
Gurtner, H. P. (1969a). Åtiologie und Häufigkeit der primăr vaskulären Formen des chronischen Cor pulmonale. Dtsch. med. Wschr., 94, 850.

(1969b). Pulmonary hypertension produced by ingestion of substances. Bull. Physio-Path. Resp., 5, 435.

(1970). Hypertensive pulmonary vascular disease. Some remarks on its incidence and etiology. Proceedings of the Twelfth Annual Meeting of the European Society for the Study of Drug Toxicity, Uppsala, Sweden, June 1970. Excerpta Medica Foundation, Amsterdam. In press.

- Gertsch, M., Salzmann, C., Scherrer, M., Stucki, P., and Wyss, F. (1968). Häufen sich die primär vasculären Formen des chronischen Cor pulmonale? Schweiz. med. Wschr., 98, 1579 and 1695.

Hasleton, P. S., Heath, D., and Brewer, D. B. (1968). Hypertensive pulmonary vascular disease in states of chronic hypoxia. J. Path. Bact., 95, 431.

Heath, D., and Edwards, J. E. (1958). The pathology of hypertensive pulmonary vascular disease. Circulation, 18, 533.

_ and Kay, J. M. (1967). Medial thickness of pulmonary trunk in rats with cor pulmonale induced by ingestion of Crotalaria spectabilis seeds. Cardiovasc. Res., 1, 74.

Jornod, J., Widgren, S., and Fischer, G. (1970). Etude anatomo-clinique d'un cas d'hypertension artérielle pulmonaire chez une jeune femme. Schweiz. med. Wschr., 100, 151.

Kaindl, F. (1969). Primäre pulmonale hypertension. Wien. Z. inn. Med., 50, 451.
Kay, J. M., Harris, P., and Heath, D. (1967). Pulmonary hypertension produced in rats by ingestion of Crotalaria spectabilis seeds. Thorax, 22, 176.

- and Heath, D. (1966). Observations on the pulmonary arteries and heart weight of rats fed on Crotalaria spectabilis seeds. J. Path. Bact., 92, 385.

(1969). Crotalaria Spectabilis the Pulmonary Hypertension Plant, p. 56. Thomas, Springfield, Illinois.

Smith, P., Bras, G., and Summerell, Joan (1971). Fulvine and the pulmonary circulation. Thorax, 26, 249.

Kraupp, O., Stühlinger, W., Raberger, G., and Turnheim, K. (1969). Die Wirkung von Aminorex (Menocil) auf die Hämodynamik des kleinen und grossen Kreislaufs bei i.v. Darreichung am Hund. Naunyn-Schmiedeberg's Arch. exp. Path. Pharmak., 264, 389.

Lang, E., Haupt, E. J., Köhler, J. A., and Schmidt, J. (1969). Cor pulmonale durch Appetitzügler? Münch. med. Wschr., 111, 405.

Obiditsch-Mayer, I. (1969). Lingulabiopsien bei Patienten mit primärer pulmonaler Hypertonie. Wien. Z. inn. Med., 50, 486.

Peters, L. (1970). Pharmacological, toxicological and clinical observations with aminorex in the United States. Read at a symposium on Obesity, circulation and anorexigens, May 15 and 16, Lucerne, Switzerland.

Rivier, J.-L. (1970). Hypertension artérielle pulmonaire primitive. Schweiz. med. Wschr., 100, 143.

Wagenvoort, C. A., Heath., D., and Edwards, J. E. (1964). The Pathology of the Pulmonary Vasculature, p. 172. Thomas, Springfield, Illinois. 